\author{
Jan Piątkowski \\ Uniwersytet Mikołaja Kopernika, Toruń \\ janter@umk.pl \\ ORCID: https://orcid.org/0000-0001-5249-9024

\section{Beata Rutkowska} \\ Uniwersytet Mikołaja Kopernika, Toruń \\ beatarut@umk.pl \\ ORCID: https://orcid.org/0000-0002-1920-8261
}

\title{
Glosa do wyroku Sądu Najwyższego $z$ dnia 14 grudnia 2017 r., II PK 322/16
}

http://dx.doi.org/10.12775/SIT.2019.029

Tezy wyroku: udział w kilkudniowym szkoleniu organizowanym przez związek zawodowy nie jest wykonywaniem doraźnej czynności wynikającej z funkcji związkowej, a działacz związkowy nie ma prawa do zwolnienia od pracy $z$ zachowaniem prawa do wynagrodzenia na czas niezbędny do udziału w takim szkoleniu (art. 31 ust. 3 Ustawy z dnia 23 maja 1991 r. o związkach zawodowych, tekst jednolity: Dz.U. z 2015 r., poz. 1881).

Kilkudniowe szkolenie organizowane przez związek zawodowy w godzinach przeznaczonych na pracę nie stanowi czynności, o której mowa w art. 31 ust. 3 Ustawy $z$ dnia 23 maja 1991 r. o związkach zawodowych (tekst jednolity: Dz.U. z 2015 r., poz. 1881).

Pojęcie pracy o jednakowej wartości determinowane jest kilkoma czynnikami (chodzi o porównywalne kwalifikacje i doświadczenie 
zawodowe). Wymienione mierniki koncentrują uwagę na osobie pracownika. Niezależnie jednak od nich ustawodawca przywiązuje wagę do stopnia odpowiedzialności i wysiłku. Czynniki te mają charakter przedmiotowy i wiążą się z właściwościami przypisanymi do danego stanowiska pracy. Prace będą jednakowe, gdy wskazane aspekty, ocenianie łącznie, wykażą podobieństwo, a precyzyjniej: będą porównywalne.

Różnice w wysokości wynagrodzeń mające oparcie w obiektywnych zmiennych (jak np. kwalifikacje, doświadczenie zawodowe, zakres odpowiedzialności pracownika, rodzaj wykonywanej pracy i jej znaczenie dla pracodawcy, szczególne potrzeby pracodawcy, natężenie obowiązków poszczególnych pracowników) nie świadczą o naruszeniu zasady równego traktowania w zatrudnieniu lub dyskryminacji ze względu na działalność związkową (art. 18 ${ }^{3 \mathrm{~b}} \S 1$ oraz art. $18^{3 a} \S 1$ k.p.).

W glosowanym wyroku Sąd Najwyższy zajął się problematyką dotyczącą naruszenia zasady równego traktowania w zatrudnieniu. $Z$ jednej strony skoncentrował się na ocenie, czy różnice w wysokości wynagrodzenia poszczególnych pracowników świadczą o dyskryminacji, $z$ drugiej strony wypowiedział się na temat nieudzielania przez pracodawcę zwolnień od pracy zawodowej z zachowaniem prawa do wynagrodzenia na czas niezbędny do udziału w kilkudniowych szkoleniach związkowych. Rozważania przeprowadzone w obydwu aspektach były kluczowe w przedmiotowej sprawie. Miały bowiem na celu ustalenie, czy pracownica (powódka) była dyskryminowana i co za tym idzie - czy dochodzenie przez nią odszkodowania z tytułu dyskryminacji oraz zadośćuczynienia za naruszenie dóbr osobistych było uzasadnione.

Wyrok został wydany w następującym stanie faktycznym. Powódka była zatrudniona na podstawie umowy o pracę na stanowisku starszego specjalisty ds. inwestycji w dziale inwestycji. Odpowiadała za sprawy dotyczące utrzymania zieleni. Realizowała także inne zadania, m.in. z zakresu inwestycji i archiwizacji dokumentów. Przy wykonywaniu swoich obowiązków niejednokrotnie korzystała z pomocy innych pracowników. W związku z brakiem środków finansowych na nowe inwestycje w zieleń obowiązki pracownicze powódki ulegały stopniowemu zmniejszeniu. W lipcu 2011 r. w dziale 
inwestycji została zatrudniona nowa pracownica na stanowisku specjalisty ds. inwestycji i remontów. Do zakresu jej obowiązków należało przede wszystkim zajmowanie się remontami, współpracą w zakresie inwestycji, prowadzeniem książek obiektów budowlanych oraz gwarancjami wcześniej wykonywanych obiektów budowlanych. Powódka należała do XV kategorii zaszeregowania zgodnie $z$ tabelą stawek miesięcznego wynagrodzenia zasadniczego, a jej wynagrodzenie obejmowało $2585 \mathrm{zł}$ wynagrodzenia zasadniczego i dodatek funkcyjny w kwocie 1 zł. Nowa pracownica została zaszeregowana do kategorii XIV i otrzymywała wynagrodzenie w wysokości $2600 \mathrm{zl}$. Przyznano jej także dodatek specjalny w kwocie 1300 zł. Porównanie swojego wynagrodzenia $z$ wynagrodzeniem nowej pracownicy działu inwestycji w połączeniu $z$ ustaleniem otrzymywania o wiele niższego dodatku funkcyjnego od innych pracowników skłoniło powódkę do uznania, że jest dyskryminowana przez pracodawcę. Poza niższym wynagrodzeniem za dodatkowy przejaw dyskryminacji powódka uważała nieudzielanie jej przez pracodawcę zwolnień z obowiązku świadczenia pracy z zachowaniem prawa do wynagrodzenia w celu udziału w kilkudniowych szkoleniach organizowanych przez związek zawodowy. Jako przewodnicząca koła reprezentowała ona u pracodawcy Międzyzakładową Komisję Pracowników Biura Zarządu Regionu G. Powódka wniosła o zasądzenie od pracodawcy odszkodowania $z$ tytułu dyskryminacji w zatrudnieniu oraz zadośćuczynienia za naruszenie dóbr osobistych.

Sąd I instancji dokonał analizy i porównania wynagrodzenia powódki i innych pracowników zatrudnionych u pozwanego na stanowisku specjalisty lub starszego specjalisty ze szczególnym uwzględnieniem pracownicy pracującej w tym samym dziale co powódka. Na podstawie dokonanych ustaleń sąd przyjął, że powódka nie była dyskryminowana. Podkreślił, że nieznaczne różnice w wynagrodzeniu pracowników, będące wynikiem oceny jakości ich pracy przez przełożonego, nie powinny być, co do zasady, traktowane jako naruszające zasadę równego traktowania. Dodatkowo stwierdził, że powódka jako jedyna spośród pracowników, którzy nie kierowali zespołami, otrzymywała dodatek funkcyjny. Gdyby dodatek ten został jej przyznany w wysokości 550 zł, jak się tego domagała, oznaczałoby to deprecjację całej dodatkowej pracy, którą 
wykonywali pracownicy kierujący zespołami. Sąd uznał też, że wobec powódki nie doszło do dyskryminacji $z$ uwagi na dostęp do szkoleń. W konsekwencji sąd I instancji oddalił powództwo. Sąd II instancji podzielił zapatrywania sądu I instancji i oddalił apelację powódki. W przekonaniu tego sądu zróżnicowanie w zakresie wynagrodzenia powódki $z$ innymi pracownikami, w tym $z$ pracownicą zajmującą w dziale inwestycji stanowisko specjalisty ds. inwestycji i remontów, było uzasadnione i usprawiedliwione okolicznościami, nie było też rażące i odbiegające od zasad wynagradzania obowiązujących u pracodawcy, tak aby można mówić o dyskryminacji. Sąd II instancji nie uznał też za dyskryminujące działań pracodawcy polegających na niewyrażaniu zgody na zwolnienie powódki z obowiązku świadczenia pracy z zachowaniem prawa do wynagrodzenia w celu odbycia kilkudniowego szkolenia związkowego. Sąd Najwyższy uznał skargę kasacyjną powódki za niezasadną i ją oddalił.

W uzasadnieniu do glosowanego orzeczenia Sąd Najwyższy przyjął, że podstawową kwestią sporną jest to, czy działania pracodawcy polegające na przyznaniu powódce takiego, a nie innego wynagrodzenia i nieudzieleniu zgody na udział w szkoleniu z zachowaniem prawa do wynagrodzenia stanowiły przejaw dyskryminacji powódki ze względu na jej społeczną aktywność. Sąd Najwyższy nie dopatrzył się w tym zakresie uchybień ze strony pracodawcy. W pierwszej kolejności słusznie zauważył, że odmienne warunki pracy nie zawsze są konsekwencją czynników uznanych za dyskryminujące. Powołując się m.in. na standardy międzynarodowe, podkreślił, że różnice w traktowaniu pracowników stanowią dyskryminację wówczas, gdy nie istnieje obiektywne i rozsądne uzasadnienie takiego rozróżnienia, a to z kolei wymaga zindywidualizowanej oceny stanu faktycznego. Sąd Najwyższy wyraził przekonanie, że okoliczności faktyczne rozpoznawanej sprawy były na tyle miarodajne, iż nie było podstaw do uznania nierówności występujących między powódką a innymi pracownikami za przejaw dyskryminacji z uwagi na działalność związkową. Zgodził się z twierdzeniem sądu II instancji, że wpływ na odmienne ukształtowanie wysokości wynagrodzenia powódki miała nie jej działalność związkowa, a inne czynniki (takie jak kwalifikacje, szczególne potrzeby pracodawcy, rodzaj wyko- 
nywanej pracy i jej znaczenie dla pracodawcy, a także natężenie obowiązków poszczególnych pracowników). Biorąc pod uwagę to, że pracownicy mają prawo do jednakowego wynagrodzenia za jednakową pracę lub za pracę o jednakowej wartości (art. 18 ${ }^{3 \mathrm{c}}$ k.p.), Sąd Najwyższy przekonująco dowiódł, że w przedmiotowej sprawie nie doszło do naruszenia zasady równego traktowania w zakresie wynagradzania, ponieważ powódka i inni pracownicy, także zatrudnieni w tym samym co ona dziale, wykonywali różne prace - i to zarówno w aspekcie podmiotowym (kwalifikacje i doświadczenie zawodowe), jak i przedmiotowym (stopień odpowiedzialności i wysiłku). Należy w pełni podzielić również konkluzję Sądu Najwyższego, że przyznanie powódce dodatku funkcyjnego na poziomie 1 zł nie stanowiło wprawdzie przejawu jej dyskryminacji z uwagi na prowadzoną działalność związkową, niemniej jednak nie było prawidłowe. Ustalenie wskazanego dodatku w tak niskiej wysokości należy ocenić jako działanie pozorowane, pozbawione wartości ekonomicznej, które nie ma nic wspólnego $\mathrm{z}$ realizowaniem prawa podmiotowego do świadczenia pieniężnego.

Jakkolwiek przedstawiona wyżej teza o braku dyskryminacji płacowej powódki jest w pełni przekonująca, to jednak wątpliwości budzi stanowisko, jakie Sąd Najwyższy zajął w ramach drugiego, równolegle prowadzonego wątku dotyczącego nieudzielania przez pracodawcę odpłatnych zwolnień od pracy w celu udziału w szkoleniach związkowych. Zastrzeżenia wynikają $z$ jednej strony $z$ nie do końca przekonujących argumentów przytoczonych przez Sąd Najwyższy na poparcie swojego zapatrywania, $z$ drugiej strony z pominięcia niektórych - jak się wydaje, istotnych - aspektów rozważanego zagadnienia.

Sąd Najwyższy za punkt wyjścia w rozważaniach nad doraźnymi zwolnieniami związkowymi przyjął art. 80 zd. 2 k.p., zgodnie z którym za czas niewykonywania pracy pracownik zachowuje prawo do wynagrodzenia tylko wówczas, gdy przepisy prawa pracy tak stanowią ${ }^{1}$ Uznał, że konstrukcja art. 31 ust. 3 ustawy o związkach

${ }^{1}$ Ustawa z dnia 26 czerwca 1974 r. Kodeks pracy (tekst jednolity: Dz.U. z 2019 r. poz. 1040 ze zm.), dalej: k.p. 
zawodowych $^{2}$ ma charakter wyjątku, ustanawia bowiem prawo do zwolnienia od pracy $\mathrm{z}$ zachowaniem prawa do wynagrodzenia, a zatem stanowi przypadek odejścia od ogólnej reguły wyrażonej w art. 80 zd. 1 k.p., że wynagrodzenie przysługuje za pracę wykonaną. Na tej podstawie Sąd Najwyższy doszedł do przekonania, że prawo do zwolnienia doraźnego, ze względu na cechę wyjątkowości, nie może podlegać wykładni rozszerzającej. W konsekwencji wyraził stanowisko, że doraźność zawiera element nagłości i krótkotrwałości, działacz związkowy musi bowiem mieć sposobność wykonania czynności, której nie dało się przewidzieć wcześniej. Uznał ponadto, że $z$ tego samego powodu czynność doraźna musi być istotna $z$ uwagi na pełnienie funkcji związkowej.

Takie rozumienie zwrotu „wykonywanie doraźnej czynności wynikającej z funkcji związkowej”, choć świadczy o nowatorskim podejściu do zagadnienia, nie przekonuje $z$ wielu powodów. Pomiędzy poszczególnymi tezami składającymi się na całość wywodów Sądu Najwyższego na temat zwolnień doraźnych nie ma właściwego stosunku wynikania o charakterze logiczno-prawnym. Przede wszystkim brakuje uzasadnionych podstaw do przyjęcia, że między art. 80 zd. 2 k.p. a zwolnieniami doraźnymi uregulowanymi w ustawie o związkach zawodowych zachodzi prawny stosunek wynikania mający decydujący wpływ na wyrokowanie w sprawie. Dotyczy to zwłaszcza uznania, że przepis przewidujący wyjątkowy charakter wypłaty gwarancyjnej determinuje sposób rozumienia doraźnej czynności związkowej, dla wykonania której pracownik pełniący funkcję związkową ma prawo do odpłatnego zwolnienia od pracy. Sąd Najwyższy bowiem właśnie na podstawie art. $80 \mathrm{zd}$. 2 k.p. sformułował wniosek, że doraźność zawiera element nagłości i krótkotrwałości, co z kolei oznacza, że kilkudniowe szkolenie organizowane przez związek zawodowy w godzinach przeznaczonych na pracę nie jest czynnością doraźną.

Takie kategoryczne przesądzenie sprawy wydaje się zabiegiem co najmniej wątpliwym z punktu widzenia reguł wykładni prawa.

2 Ustawa z dnia 23 maja 1991 r. o związkach zawodowych (tekst jednolity: Dz.U. z 2019 r. poz. 263), dalej: u.z.z. 
Przepisy bowiem powinny być interpretowane zgodnie z zakresem ich odniesienia, zwłaszcza gdy dotyczą wynagradzania za pracę. W szczególności nie powinny podlegać wykładni rozszerzającej, jak to zdarzyło się w niniejszej sprawie. W glosowanym wyroku Sąd Najwyższy uznał normę zawartą w art. 80 k.p., dotyczącą wynagradzania za pracę, za podstawę rozumienia instytucji prawnej, która jedynie pośrednio wiąże się z problematyką wynagradzania za pracę. Istotą doraźnych zwolnień wynikających $z$ funkcji związkowej są ułatwienia organizacyjne w prowadzeniu działalności związkowej. Wynagrodzenie związane $z$ takimi zwolnieniami jest skutkiem uznania zwolnienia za doraźne, a nie źródłem jego prawnej kwalifikacji.

Argumentacja Sądu Najwyższego nie przekonuje $z$ jeszcze innego powodu. Stosując niedozwoloną wykładnię rozszerzającą normy zawartej w art. 80 k.p., sąd poszedł jednocześnie w zupełnie odwrotnym kierunku, również budzącym wątpliwości. Uznał, bez wiarygodnych podstaw prawnych, niejako $z$ samego założenia, że w kontekście art. 80 zd. 2 k.p. w zw. z art. 31 ust. 3 u.z.z. zwrot o doraźnej czynności związkowej należy interpretować skrajnie zawężająco, co skutkuje przyjęciem, że rozumienie tego zwrotu powinno być odnoszone do takich wyznaczników, jak nagłość i krótkotrwałość czynności oraz doniosłość przyczyny zwolnienia z punktu widzenia pełnienia funkcji związkowej. Zastosowanie tak drastycznie zawężającej interpretacji pozwalającej na wykluczenie czynności, które można było wcześniej przewidzieć, wykładni minimalizującej długość okresu zwolnienia i gloryfikującej przyczynę doraźnego zwolnienia pozwoliło Sądowi Najwyższemu zgodzić się w rozpoznawanej sprawie $z$ oceną pracodawcy, że kilkudniowe szkolenie związkowe nie jest czynnością doraźną i co za tym idzie - nieudzielenie odpłatnego zwolnienia od pracy w celu udziału w takim szkoleniu nie stanowi naruszenia art. 31 ust. 3 u.z.z. ani przejawu dyskryminacji pracownicy. W ten sposób Sąd Najwyższy zwolnił się z przeprowadzenia szerszych rozważań co do tego, czy przyczyną odmowy przez pozwanego udzielenia powódce odpłatnego zwolnienia nie była jednak jej przynależność do organizacji związkowej.

Przyjęcie przez Sąd Najwyższy skrajnie zawężającej interpretacji zwrotu „doraźna czynność wynikająca z funkcji związkowej” budzi wątpliwości nie tylko dlatego, że jest nienależycie uzasadniona, co 
samo w sobie stawia tę interpretację pod znakiem zapytania, ale także ze względu na daleko idące konsekwencje, do jakich w ostateczności prowadzi. Jedną z nich, niezwykle istotną, jest ograniczenie autonomii związku zawodowego w prowadzeniu ustawowej i statutowej działalności. Wyjątkowo wąskie ujęcie doraźności czynności związkowej, nieoparte na wyraźnej podstawie prawnej, powoduje ograniczenie związkowców w możliwości korzystania z tego jakże istotnego ułatwienia w pełnieniu funkcji przedstawicielskiej. Osłabia też pozycję organizacji związkowej wobec pracodawcy i - co za tym idzie - negatywnie wpływa na różne obszary jej aktywności.

Interpretując art. 31 ust. 3 u.z.z. przez pryzmat art. 80 k.p., Sąd Najwyższy nie przeprowadził rozważań co do tego, czy na gruncie samej ustawy o związkach zawodowych, która stwarza podstawę do doraźnych zwolnień, jest możliwe ustalenie treści tego pojęcia. Ta właśnie regulacja, jak się wydaje, powinna mieć kluczowe znaczenie dla wyrokowania w przedmiotowej sprawie. Sąd Najwyższy przyjął jedynie, o czym była już mowa, że w kontekście art. 80 zd. 2 k.p. konstrukcja art. 31 ust. 3 u.z.z. ma charakter wyjątku. Uznał też, że w sprawie ma znaczenie kontekst sytuacyjny ${ }^{3}$ oraz przytoczył pogląd prezentowany w literaturze przedmiotu, że o doraźności czynności świadczą każdorazowo usprawiedliwione okoliczności, które muszą być niezależne temporalnie od decyzji organizacji związkowej ${ }^{4}$. Tymczasem w nauce prawa i częściowo w judykaturze na gruncie ustawy o związkach zawodowych wyrażane są przeciwstawne poglądy dotyczące tego zagadnienia. $Z$ jednej strony doraźne zwolnienia łączy się z czynnościami niecierpiącymi zwłoki, podejmowanymi w określonym dniu jako niezbędne do zachowania praw związku, jego członków lub innych pracowników, którym związek zapewnia ochronę ${ }^{5}$ lub czynnościami, które są „jednorazowe, niecierpiące zwłoki, natychmiastowe, dorywcze lub krótkotrwałe (czasowe)”, niemożliwe do zaplanowania czy przewi-

${ }^{3}$ W tym zakresie Sąd Najwyższy odwołał się do wyroku SN z dnia 6 czerwca 2001 r., I PKN 460/00, Lex nr 52259.

${ }^{4}$ K.W. Baran, w: System prawa pracy, tom V, Zbiorowe prawo pracy, red. K.W. Baran, Warszawa 2014, s. 933.

${ }^{5}$ Wyrok SN z dnia 6 czerwca 2001 r., I PKN 460/00, Lex nr 52259. 
dzenia konieczności ich wykonania oraz prowadzące do określonego celu ${ }^{6} . Z$ drugiej strony czynności doraźne są odnoszone do każdego racjonalnego przypadku (okoliczności) ${ }^{7}$. W tej ostatniej konwencji doraźność jest traktowana jako synonim konieczności (niezbędności) podjęcia czynności mieszczącej się w obszarze sprawowanej funkcji, a szerzej - w ramach normalnego funkcjonowania związków zawodowych. W tym ujęciu cechą definiującą, a zarazem wystarczającą do charakterystyki pojęcia „doraźna czynność” jest właśnie niezbędność jej wykonania, natomiast planowanie tej czynności, jej krótkookresowość czy chociażby nagłość są cechami przypadkowymi, zależnymi od konkretnego przypadku ${ }^{8}$.

To, jak na gruncie art. 31 ust. 3 u.z.z. należy rozumieć doraźność czynności wynikających z funkcji związkowej, jest niezwykle istotne dla rozpoznawanej sprawy $z$ tego względu, że determinuje kwalifikację prawną szkoleń związkowców ${ }^{9}$. Przy zastosowaniu wąskiej interpretacji udział związkowców w szkoleniach nie jest zaliczany do czynności doraźnych. Wychodzi się bowiem z założenia, że skoro szkolenia są planowane, to nie są nagłe czy niecierpiące zwłoki. Dodatkowymi czynnikami, które bierze się pod uwagę, odmawiając szkoleniom cechy doraźności, jest to, kto je organizuje (czy zależą one od decyzji związków zawodowych) i jak długo trwają. W tym kontekście reprezentatywne jest stanowisko wyrażone w nauce, zgodnie $z$ którym „długotrwałe zwolnienia na cele szkoleniowo-dydaktyczne (np. kilkudniowe) nie posiadają ustawowego przymiotu czynności doraźnej”, a ,jedynym wyjątkiem w tym zakresie są szkolenia w terminach niezależnych od organizacji związkowych przygotowywane przez organy administracji publicznej, na przykład

${ }^{6}$ B. Cudowski, Doraźne zwolnienia od pracy pracowników pełniacych funkcje związkowe, „Praca i Zabezpieczenie Społeczne” 2004, nr 8, s. 28.

7 Por. L. Morawski, Wykładnia w orzecznictwie sądów. Komentarz, Toruń 2002, s. 121.

${ }^{8}$ Szerzej J. Piątkowski, Doraźne zwolnienia od pracy $w$ ustawie o związkach zawodowych, w: Zwiazkowe przedstawicielstwo pracowników zakładu pracy, red. Z. Hajn, Warszawa 2012, s. 474 i n.

$9 \mathrm{~W}$ literaturze przedmiotu od dłuższego czasu nie ma zgodności poglądów na ten temat. Zob. np. Z. Salwa, Uprawnienia związków zawodowych, Bydgoszcz 1998, s. 162 i B. Cudowski, Doraźne zwolnienia, s. 28. 
Państwową Inspekcję Pracy"10. Inna kwalifikacja jest dokonywana natomiast wówczas, gdy przyjmuje się szerokie rozumienie doraźności. W takim przypadku uczestnictwo w szkoleniach traktuje się jako wykonywanie czynności doraźnych, jeżeli udział w nich jest konieczny (niezbędny) ze względu na sprawowaną funkcję związkową - i to niezależnie od tego, czy organizatorem szkoleń są związki zawodowe, do których należą związkowcy, i czy szkolenia te planuje się na kilka dni w ciągu tygodnia pracy ${ }^{11}$.

Sąd Najwyższy pozostawił poza zakresem swoich rozważań także inne zagadnienie istotne dla przedmiotowej sprawy. Chodzi mianowicie o rolę, jaką odgrywa pracodawca w zakresie udzielania zwolnień doraźnych. Nie analizując bliżej wskazanej kwestii, Sąd Najwyższy przyjął niejako z założenia, że pracodawca mógł odmówić powódce zwolnienia od pracy z zachowaniem prawa do wynagrodzenia. Tymczasem nie jest to wcale tak jednoznaczne. Zastrzeżenia są w głównej mierze motywowane brakiem odrębnych regulacji dotyczących tej kwestii i małej przydatności rozporządzenia w sprawie sposobu usprawiedliwiania nieobecności w pracy oraz udzielania pracownikom zwolnień od pracy ${ }^{12}$. Nie ulega wątpliwości, że niedopuszczalne jest samodzielne decydowanie przez związkowców o korzystaniu ze zwolnień ${ }^{13}$. Konieczne jest złożenie odpowiedniego wniosku do pracodawcy, w którym powinna być wskazana przyczyna danego zwolnienia oraz przewidywany czas jej trwania ${ }^{14}$. Nie oznacza to jednak, że pracodawca dysponuje swobodą w zakresie

${ }^{10}$ K.W. Baran, w: Zbiorowe prawo zatrudnienia. Komentarz, red. K.W. Baran, Warszawa 2019, s. 211.

11 J. Piątkowski, Doraźne zwolnienia, s. 489.

12 Tekst jednolity: Dz.U. z 2014 r. poz. 1632. Por. wyrok SN z dnia 13 stycznia 2005 r., II PK 117/04, OSNP 2005, nr 16, poz. 246. Sąd Najwyższy uznał w tym orzeczeniu, że zwolnienie pracownika od pracy zawodowej na czas niezbędny do wykonania doraźnej czynności wynikającej z jego funkcji związkowej następuje według zasad przewidzianych w rozporządzeniu w sprawie sposobu usprawiedliwiania nieobecności w pracy oraz udzielania pracownikom zwolnień od pracy.

13 Zob. np. wyrok SN z dnia 2 czerwca 2010 r., II PK 367/09, Lex nr 786010 oraz wyrok SN z dnia 18 lutego 2011 r., II PK 196/10, Lex nr 811847.

${ }^{14}$ Por. np. B. Cudowski, Doraźne zwolnienia, s. 29 oraz J. Piątkowski, Doraźne zwolnienia, s. 491. 
podjęcia decyzji o udzieleniu zwolnienia. Prawo związkowców do zwolnienia od pracy zawodowej nie zależy bowiem od jego uznania, ale od istnienia obiektywnych przesłanek określonych w przepisach prawnych ${ }^{15}$. W tym sensie Sąd Najwyższy słusznie zwrócił uwagę $\mathrm{w}$ glosowanym wyroku na znaczenie kontekstu sytuacyjnego. Problem polega jednak na tym, czy pracodawca, rozpatrując wniosek, może odmówić udzielenia zwolnienia od pracy. W nauce prawa pracy wyrażane są różne zapatrywania na ten temat. Część doktryny opowiada się za taką właśnie możliwością ${ }^{16}$. Prezentowany jest jednak także pogląd odmienny, w którym - mając na względzie autonomię związków zawodowych - uznaje się, że art. 31 ust. 3 u.z.z. przyjmuje domniemanie wiarygodności ujawnionych we wniosku okoliczności związanych $z$ doraźnym zwolnieniem, co przesądza o bezwzględnym charakterze obowiązku udzielenia tego zwolnienia, a jedynym środkiem służącym do kwestionowania decyzji w przedmiocie doraźnego zwolnienia dla celów związkowych jest konstrukcja nadużycia prawa (art. 8 k.p.) ${ }^{17}$.

W kontekście rozpoznawanej sprawy szczególnie istotna wydaje się niekonsekwencja pracodawcy w zakresie udzielania powódce zwolnień w celu jej udziału w kilkudniowych szkoleniach związkowych $z$ zachowaniem prawa do wynagrodzenia. Sąd Najwyższy w ogóle nie odniósł się do tego, że w grudniu 2012 r. pracodawca wyraził zgodę na udział powódki w dłuższym szkoleniu zorganizowanym przez Zarząd Regionu G. NSZZ „Solidarność”, przez co uznał takie zwolnienie za doraźne w rozumieniu ustawy o związkach zawodowych, a dopiero później zaczął kwestionować doraźny charakter szkoleń związkowych. Wysoce dyskusyjna wydaje się także propozycja pracodawcy składana przy okazji kolejnych wniosków o zgodę na udział powódki w kilkudniowych szkoleniach związkowych, aby pracownica uczestniczyła w tych szkoleniach w ramach urlopu wypoczynkowego lub bezpłatnego. Można mieć

15 Zob. wyrok SN z dnia 6 czerwca 2001 r., I PKN 460/00, Lex nr 52259.

${ }^{16}$ Zob. np. B. Cudowski, Doraźne zwolnienia, s. 28 i Ł. Pisarczyk, Reforma zbiorowego prawa pracy. Próba kodyfikacji a nowelizacja przepisów zbiorowego prawa pracy, Warszawa 2019, s. 332 i n.

17 J. Piątkowski, Doraźne zwolnienia, s. 490 i n. 
poważne wątpliwości co do legalności tej propozycji. Zagadnienie to nie zostało jednak poddane analizie w glosowanym orzeczeniu.

Dotychczasowe rozważania uprawniają do konstatacji, że o ile w kwestii braku dyskryminacji płacowej powódki stanowisko Sądu Najwyższego jest w pełni przekonujące, o tyle zastrzeżenia budzi zapatrywanie wyrażone w przedmiocie szkoleń związkowych. W glosowanym orzeczeniu Sąd Najwyższy uznał, że doraźność zwolnień od pracy odnosi się do czynności krótkotrwałych, nagłych i uzasadnionych istotną potrzebą związkową. Taki pogląd wywiódł z treści art. 80 k.p. i to wywołuje zasadnicze wątpliwości. Podstawą do określenia znaczenia terminu „doraźna czynność wynikająca $z$ funkcji związkowej" powinna być bowiem regulacja zawarta w ustawie o związkach zawodowych, która wprost dotyczy tej instytucji, a nie art. 80 k.p. normujący w rzeczywistości odmienną materię, tj. wynagradzanie za pracę.

Praktyka zakładowa jednoznacznie wskazuje, że spory interpretacyjne powstające na tle rozumienia pojęcia doraźnej czynności wynikającej z funkcji związkowej negatywnie wpływają na relacje między pracodawcą i związkami zawodowymi. Wobec ogólnego brzmienia art. 31 ust. 3 u.z.z. to właśnie do Sądu Najwyższego należy wyjaśnienie tego pojęcia, zwłaszcza że od dłuższego czasu kwestia ta jest przedmiotem sporów w nauce prawa. Ogólne brzmienie art. 31 ust. 3 u.z.z mogłoby też prowadzić do odmiennych ustaleń, a mianowicie do przyjęcia alternatywnego rozstrzygnięcia opartego na ocenie prawidłowości korzystania przez pracownika $z$ prawa do dłuższych szkoleń związkowych w ramach doraźnych zwolnień związkowych (art. 8 k.p.). Taka ocena miałaby charakter zindywidualizowany, odnosiłaby się do konkretnego stanu faktycznego.

\section{STRESZCZENIE}

Glosa do wyroku Sądu Najwyższego z dnia 14 grudnia 2017 r., II PK 322/16

Przedmiotem glosowanego wyroku jest problematyka dotycząca naruszania zasady równego traktowania w zatrudnieniu. O ile Sąd Najwyższy przeko- 
nująco dowiódł, że nie można mówić o naruszeniu tej zasady, gdy różnice w wysokości wynagrodzenia poszczególnych pracowników wynikają z wykonywania przez nich różnych prac - i to zarówno w aspekcie podmiotowym (kwalifikacje i doświadczenie zawodowe), jak i przedmiotowym (stopień odpowiedzialności i wysiłku), o tyle wątpliwości budzi teza sformułowana w ramach rozważań dotyczących nieudzielania przez pracodawcę doraźnych zwolnień związkowych. Sąd Najwyższy uznał, że nieudzielenie odpłatnego zwolnienia od pracy w celu udziału w kilkudniowym szkoleniu związkowym nie stanowi naruszenia art. 31 ust. 3 u.z.z. ani przejawu dyskryminacji pracownika, ponieważ doraźność zwolnienia od pracy odnosi się do czynności krótkotrwałych, nagłych i uzasadnionych istotną potrzebą związkową. Taki pogląd wywiódł z treści art. 80 k.p. Tymczasem podstawą do określenia znaczenia terminu „doraźna czynność wynikająca $z$ funkcji związkowej” powinna być regulacja zawarta w ustawie o związkach zawodowych, która wprost dotyczy tej instytucji, a nie art. 80 k.p. normujący w rzeczywistości odmienną materię, tj. wynagradzanie za pracę.

Słowa kluczowe: zasada równego traktowania w zatrudnieniu; zakaz dyskryminacji; doraźne zwolnienia związkowe; szkolenia związkowe; wynagrodzenie za pracę

\section{SUMMARY}

\section{Gloss to the judgement of the Supreme Court of 14 December 2017, II PK 322/16}

The subject matter of the judgement are the issues concerning the violation of the principle of equal treatment in employment. While the Supreme Court has convincingly proved that it is not the violation of the said principle if the differences in remuneration of given employees result from their performance of diverse jobs - both in the objective context (qualifications and professional experience) and the subjective one (level of liability and effort), the doubts are caused by the thesis expressed as part of consideration concerning a failure of an employer to grant interim leaves of a trade union nature. The Supreme Court has decided that a failure to grant paid leave to an employee so that they could participate in a few-day trade union training does not constitute a violation of Article 31, section 3 of the Act on trade union organizations, nor it is a form of discrimination of the employee, since the interim leave from work refers to short-term, sudden activities justified by a crucial need of a trade union nature. This view stems from the content of Article 80 of the Labour Code. The basis 
for stating the meaning of a term "interim activity resulting from a trade union function" should not be Article 80 of the Labour Code which in fact regulates a different matter, i.e. remuneration for work, but a regulation provided for in the Act on trade union organizations, which refers directly to this institution.

Keywords: principle of equal treatment in employment; prohibition of discrimination; interim leaves of a trade union nature; trade union trainings; remuneration for work

\section{BIBLIOGRAFIA}

Baran K.W., w: System prawa pracy, tom V, Zbiorowe prawo pracy, red. K.W. Baran, Warszawa 2014.

Baran K.W., w: Zbiorowe prawo zatrudnienia. Komentarz, red. K.W. Baran, Warszawa 2019.

Cudowski B., Doraźne zwolnienia od pracy pracowników petniących funkcje zwiazkowe, „Praca i Zabezpieczenie Społeczne” 2004, nr 8.

Morawski L., Wyktadnia w orzecznictwie sądów. Komentarz, Torun 2002. Piątkowski J., Doraźne zwolnienia od pracy $w$ ustawie o zwiazkach zawodowych, w: Zwiazkowe przedstawicielstwo pracowników zakładu pracy, red. Z. Hajn, Warszawa 2012.

Pisarczyk Ł., Reforma zbiorowego prawa pracy. Próba kodyfikacji a nowelizacja przepisów zbiorowego prawa pracy, Warszawa 2019.

Salwa Z., Uprawnienia związów zawodowych, Bydgoszcz 1998. 